\title{
Novel Pathway for the Intermolecular Cyclization of the ((Propargylthio)thiocarbonyl)diphenylphosphine Ligand in Tungsten Complexes
}

\author{
Kuang-Hway Yih, Ying-Chih Lin," Ming-Chu Cheng, and Yu Wang \\ Department of Chemistry, National Taiwan University, Taipei, Taiwan 106, Republic of China
}

Received January 26, $1994^{\circ}$

\begin{abstract}
Summary: The tungsten complex $W(\mathrm{CO})_{5}\left[\mathrm{PPh}_{2}\left(\mathrm{CS}_{2^{-}}\right.\right.$ $\left.\left.\mathrm{C}_{3} \mathrm{H}_{3}\right)\right](2)$ undergoes dimerization, giving $\mathrm{W}_{2}(\mathrm{CO})_{10}\left[\mathrm{P}_{2^{-}}\right.$ $\left.\mathrm{Ph}_{4}\left(\mathrm{C}_{8} \mathrm{H}_{6} \mathrm{~S}_{4}\right)\right]$ (3). Protonation of 2 produces the intramolecularcyclization product W(CO) ${ }_{5}\left[\mathrm{PPh}_{2}\left(\mathrm{CS}_{2} \mathrm{C}_{3} \mathrm{H}_{4}\right)\right]$ $B F_{4}(4)$, and protonation of $W(C O)_{5}\left[P P h_{2}\left(C_{2} \mathrm{CH}_{2} \mathrm{C} \equiv N\right)\right]$ (7) also gives $W(\mathrm{CO})_{5}\left[\mathrm{PPh}_{2}\left(\mathrm{CS}_{2} \mathrm{C}_{2} \mathrm{NH}_{3}\right)\right] B \mathrm{~F}_{4}(\mathrm{8})$, which is converted back to 7 by BuLi. The structures of 3 and 8 are determined by $X$-ray diffraction. Deuterium labeling studies along with the solvent effect clearly indicate that the dimerization involves an unprecedented $S$-assisted intermolecular cycloaddition of the propargyl and thiocarbonyl groups of 2, forming a heterocyclic fivemembered thiolene ring.
\end{abstract}

Cycloadditions which carry the ability to simultaneously form and break several bonds with a variety of atomic substitution patterns are among the most important processes in organic chemistry. ${ }^{1}$ The cyclization of metalpropargyl complexes ${ }^{2}$ and the use of the thiocarbonylgroup in such reactions ${ }^{3}$ have been previously reported. However, most of the syntheses of S-heterocycles using transition-metal species have resulted from the reaction of metallocyclopentadiene with either sulfur or carbon disulfide. ${ }^{4}$ We previously reported the synthesis of a tungsten complex containing a new $\mathrm{P}$-coordinated $\mathrm{PPh}_{2}$ $\mathrm{CS}_{2} \mathrm{R}$ ligand, ${ }^{5}$ which differs from the well-studied Scoordinated $\mathrm{zwitterionic} \mathrm{PR}_{3}{ }^{+} \mathrm{CS}_{2}$ - ligand. ${ }^{6}$ In extending our explorations to the propargyl analogue, we find that a novel cyclization reaction occurs involving the propargyl and the thiocarbonyl groups. Herein we report an unprecedented sulfur-assisted cycloaddition and proton-

- Abstract published in Advance ACS Abstracts, April 1, 1994.

(1) (a) Padwa, A., Ed. 1,3-Dipolar Cycloaddition Chemistry; Wiley: New York, 1984. (b) Curran, D. P., Ed. Advance in Cycloaddition; JAI Press: Greenwich, CT, 1988; Vol. 1. (c) Welker, M. E. Chem. Rev, 1992, $92,97$.

(2) (a) Raghu, S.; Rosenblum, M. J. Am. Chem. Soc. 1973, 95, 3060. (b) Rosenblum, M. Acc. Chem. Res. 1974, 7, 122. (c) Cutler, A.; Ehntholt, D.; Giering, W. P.; Lennon, P.; Raghu, S.; Rosan, A.; Rosenblum, M.; Tancrede, J.; Wells, D. J. Am. Chem. Soc. 1976, 98, 3495. (d) Rosenblum M. J. Organomet. Chem. 1986, 300, 191. (e) Wojcicki, A. Coord. Chem. Rev. 1990, 105, 35. (f) Wojcicki, A. In Fundamental Research in Organometallic Chemistry; Tsutsui, M., Ishii, Y., Yaozeng, H., Eds.; Van Nostrand Reinhold: New York, 1982; p 569.

(3) Huisgen, R.; Mloston, G.; Fulka, C. Heterocycles 1985, 23, 2207.

(4) Kozikowski, A. P.; Wetter, H. F. Synthesis 1976, 750.

(5) Yih, K.-H.; Lin, Y.-C.; Cheng, M.-C.; Wang, Y.J.Chem. Soc., Chem. Commun. 1993, 1380.

(6) (a) George, R. C.; Terrence, J. C.; Suzanne, M. J.; Warren, R. R.; Keith, G. T. J. Chem. Soc., Chem. Commun. 1976, 475. (b) Bianchini, C.: Innocenti, P.; Meli, A.; Orlandini, A.:Scapacci, A. J. Organomet. Chem. 1982, 233, 233. (c) Gaffney, T. R.; Ibers, J. A. Inorg. Chem. 1982, 21, 2062. (d) Bianchini, C.; Ghilardi, C. A.; Meli, A.; Orlandini, A. J. Organomet. Chem. 1983, 246, C13. (e) Baird, D. M.; Fanwick, P. E.; Barwick, T. Inorg. Chem. 1985, 24, 3753. (f) Uson, R.; Laguna, A.; Laguna, M.; Castills, M. L. J. Chem. Soc., Dalton Trans. 1987, 3017. (g) Miguel, D.; Riera, V. Organometallics 1991, 10, 1683. (h) Kreissl, F. R.; Ullrich, N.; Wirsing, A.; Thewalt, U. Organometallics 1991, 10, 3275. (i) Galindo, A.; GutierrezPuebla, E.; Monge, A.; Munoz, M. A.; Pastor, A.; Ruiz, C.; Carmona, E. J. Chem. Soc., Dalton Trans. 1992, 2307. (j) Miguel, D.; Perez-Martinez, J. A.; Riera, V. Organometallics 1993, 12, 1394. induced cyclization of this $\mathrm{W}$ complex. A deuterium labeling study leads to the elucidation of the mechanism of the cycloaddition.

Treatment of the (sulfidothiocarbonyl)diphenylphosphine complex $\mathrm{Et}_{4} \mathrm{NW}(\mathrm{CO})_{5}\left(\mathrm{PPh}_{2} \mathrm{CS}_{2}\right)(1)^{5}$ with $\mathrm{BrCH}_{2} \mathrm{C} \equiv$ $\mathrm{CH}$ in $\mathrm{CH}_{2} \mathrm{Cl}_{2}$ affords $\mathrm{W}(\mathrm{CO})_{5}\left(\mathrm{PPh}_{2} \mathrm{CS}_{2} \mathrm{C}_{3} \mathrm{H}_{3}\right)(2)$. The ${ }^{31} \mathrm{P}$ NMR spectrum of 2 in $\mathrm{CDCl}_{3}$ exhibits a resonance at $\delta 59.0$ with a tungsten satellite $\left({ }^{1} J_{\mathrm{P}-\mathrm{w}}=240.3 \mathrm{~Hz}\right)$, indicating phosphorus coordination of the ligand. This phosphorus coordination differs from the bidentate S,Scoordination of a (sulfidothiocarbonyl)phosphine ligand in a previously reported $\mathrm{Zr}$ complex. ${ }^{7}$ At room temperature complex 2 is unstable and undergoes an intermolecular cycloaddition of the propargyl and thiocarbonyl groups (see Scheme 1) to form the red crystalline complex $\mathrm{W}_{2}(\mathrm{CO})_{10}\left[\mathrm{P}_{2} \mathrm{Ph}_{4}\left(\mathrm{C}_{8} \mathrm{H}_{6} \mathrm{~S}_{4}\right)\right](3)$ in $71 \%$ isolated yield within $30 \mathrm{~min}$. In the ${ }^{1} \mathrm{H}$ NMR spectrum of $3,{ }^{8}$ two sets of resonances, each with an $A B X$ pattern, are observed: one maintains the propargylic character (i.e. terminal proton at $\delta 2.16$ ), and the other shows an allylic pattern (olefinic proton at $\delta 6.40$ ). The methylene protons of the allylic group show additional $\mathrm{P}-\mathrm{H}$ coupling with a significant $J_{\mathrm{P}-\mathrm{H}}$ value, indicating the proximity of this $\mathrm{CH}_{2}$ group and one of the $\mathrm{P}$ atoms. This implies that the transformation of 2 to 3 should involve a cycloaddition reaction resulting in $\mathrm{C}-\mathrm{C}$ bond formation between the propargyl and thiocarbonyl groups (see Scheme 1). To confirm the mode of cyclization, complex 3 was characterized by an $\mathrm{X}$-ray diffraction analysis. ${ }^{9}$ The ORTEP drawing of 3 is shown in Figure 1. It is clear that the two tungsten metal centers arebridged by a diphosphorus ligand containing a thiolene ring and the double bond of the thiolene ring is between $\mathrm{C}_{\alpha}$ and $\mathrm{C}_{\beta}$, i.e. 1.32(2) $\AA$ for the $\mathrm{C}(4)-\mathrm{C}(5)$ bond. The three significantly shorter $\mathrm{S}-\mathrm{C}\left(\mathrm{sp}^{2}\right)$ bond distances, compared to the three $\mathrm{S}-\mathrm{C}\left(\mathrm{sp}^{3}\right)$ bond distances, result from the well-known $\mathrm{d} \pi-\mathrm{p} \pi$ interaction. ${ }^{10}$ The analogous complex $\mathrm{W}(\mathrm{CO})_{6}\left[\mathrm{PPh}_{2}\left(\mathrm{CS}_{2} \mathrm{CH}_{2} \mathrm{C} \equiv \mathrm{N}\right)\right](7)$ has been prepared in high yield from the reaction of 1 with $\mathrm{ICH}_{2} \mathrm{C} \equiv \mathrm{N}$. Unlike 2, complex 7 is stable at room temperature.

(7) Hey, E.; Lappert, M. F.; Atwood, J. L.; Bott, S. G. J. Chem. Soc., Chem. Commun. 1987, 421.

(8) Selected spectral and analytical data for 3,4, and 7-9 are as follows. 3: ${ }^{31 \mathrm{P} N M R}\left(\mathrm{CDCl}_{3}, 246 \mathrm{~K}\right) \delta 42.6\left(1 J_{\mathrm{W}-\mathrm{P}}=258.2 \mathrm{~Hz}\right), 46.6\left({ }^{1} J_{\mathrm{WT}-\mathrm{P}}=247.8\right.$ $\mathrm{Hz}$ ) (two isomers), $57.9\left({ }^{1} J_{\mathrm{W}-\mathrm{P}}=247.0 \mathrm{~Hz}\right) ;{ }^{1} \mathrm{H}$ NMR $\left(\mathrm{CDCl}_{\mathrm{g}}\right) \delta 2.16(\mathrm{t}$, $\left.1 \mathrm{H}, \equiv \mathrm{CH},{ }^{4} J_{\mathrm{H}-\mathrm{H}}=2.57 \mathrm{~Hz}\right), 3.36,3.62\left(\mathrm{ABX}, 1 \mathrm{H}, \mathrm{S}-\mathrm{CH}_{2},{ }^{4} J_{\mathrm{H}-\mathrm{H}}=2.6 \mathrm{~Hz}\right.$, $\left.{ }_{4} J_{\mathrm{P}-\mathrm{H}}=16.4 \mathrm{~Hz}\right), 3.47,3.90\left(\mathrm{ABX}, 1 \mathrm{H}, \mathrm{C}-\mathrm{CH}{ }_{2} \mathrm{C},{ }^{4} J_{\mathrm{H}-\mathrm{H}}=1.7 \mathrm{~Hz}, 2 J_{\mathrm{H}-\mathrm{H}}=\right.$ $18.2 \mathrm{~Hz}), 6.40\left(\mathrm{t}, 1 \mathrm{H}, \mathrm{SC}=\mathrm{CHS}, J_{\mathrm{H}-\mathrm{H}}=1.7 \mathrm{~Hz}\right), 7.48,7.69(\mathrm{~m}, 30 \mathrm{H}, \mathrm{Ph})$; mp $160^{\circ} \mathrm{C} \mathrm{dec}$. Anal. Calcd: $\mathrm{C}, 40.40 ; \mathrm{H}, 2.10$. Found: $\mathrm{C}, 40.51 ; \mathrm{H}, 2.27$. 4: ${ }^{1} \mathrm{H}$ NMR $\delta 2.85$ (d, $\left.3 \mathrm{H}, \mathrm{CH}_{3},{ }^{4}{ }_{\mathrm{H}-\mathrm{H}}=1.0 \mathrm{~Hz}\right), 7.50(\mathrm{~m}, 6 \mathrm{H}, \mathrm{Ph}), 7.66$ $(\mathrm{m}, 4 \mathrm{H}, \mathrm{Ph}), 8.98(\mathrm{~m}, 1 \mathrm{H},=\mathrm{CH}) ;{ }^{31 \mathrm{P}} \mathrm{NMR} \delta 30.36\left(1 J_{\mathrm{W}-\mathrm{P}}=261.8 \mathrm{~Hz}\right) ;$ mp $114^{\circ} \mathrm{C}$ dec. Anal. Calcd: C, 35.42; $\mathrm{H}, 1.99$. Found: C, 35.59; H, 2.12. 7: ${ }^{31 P}$ NMR $\left(\mathrm{CDCl}_{3}\right) \delta 61.46\left({ }^{1} J_{\mathrm{WW}-\mathrm{P}}=251.9 \mathrm{~Hz}\right) ;{ }^{1} \mathrm{H} \mathrm{NMR}\left(\mathrm{CDCl}_{8}\right) \delta 3.99$ (s, $\left.2 \mathrm{H}, \mathrm{SCH}_{2} \mathrm{CN}\right), 7.48(\mathrm{~m}, 6 \mathrm{H}, \mathrm{Ph}), 7.69(\mathrm{~m}, 4 \mathrm{H}, \mathrm{Ph})$. 8: ${ }^{31 \mathrm{P}} \mathrm{NMR} \delta 21.86$ $\left({ }^{\prime} J_{\mathrm{W}-\mathrm{P}}=259.61 \mathrm{~Hz}\right)$; ${ }^{1 \mathrm{H} N M R} \delta 7.50(\mathrm{~m}, 6 \mathrm{H}, \mathrm{Ph}), 7.66(\mathrm{~m}, 4 \mathrm{H}, \mathrm{Ph}), 8.12$ (b, $2 \mathrm{H}, \mathrm{NH}, 2.8 .20$ (d, $1 \mathrm{H}, \mathrm{CH}$; mp $195^{\circ} \mathrm{C}$. Anal. Calcd: C, 33.69; $\mathrm{H}$, $1.84 ; \mathrm{N}, 1.96$. Found: C, 33.31; H, 1.97; N, 1.85. 9: $31 \mathrm{P}$ NMR $\delta 21.50$ $\left({ }^{1} J_{\mathrm{W}-\mathrm{P}}=259.0 \mathrm{~Hz}\right) ;{ }^{1 \mathrm{H}} \mathrm{NMR} \delta 8.51\left(\mathrm{~d}, 1 \mathrm{H}, H \mathrm{C}=\mathrm{C},{ }^{4} J_{\mathrm{H}-\mathrm{H}}=2.0 \mathrm{~Hz}\right)$, $7.60-7.10(\mathrm{~m}, 25 \mathrm{H}, \mathrm{Ph})$. 
Scheme 1

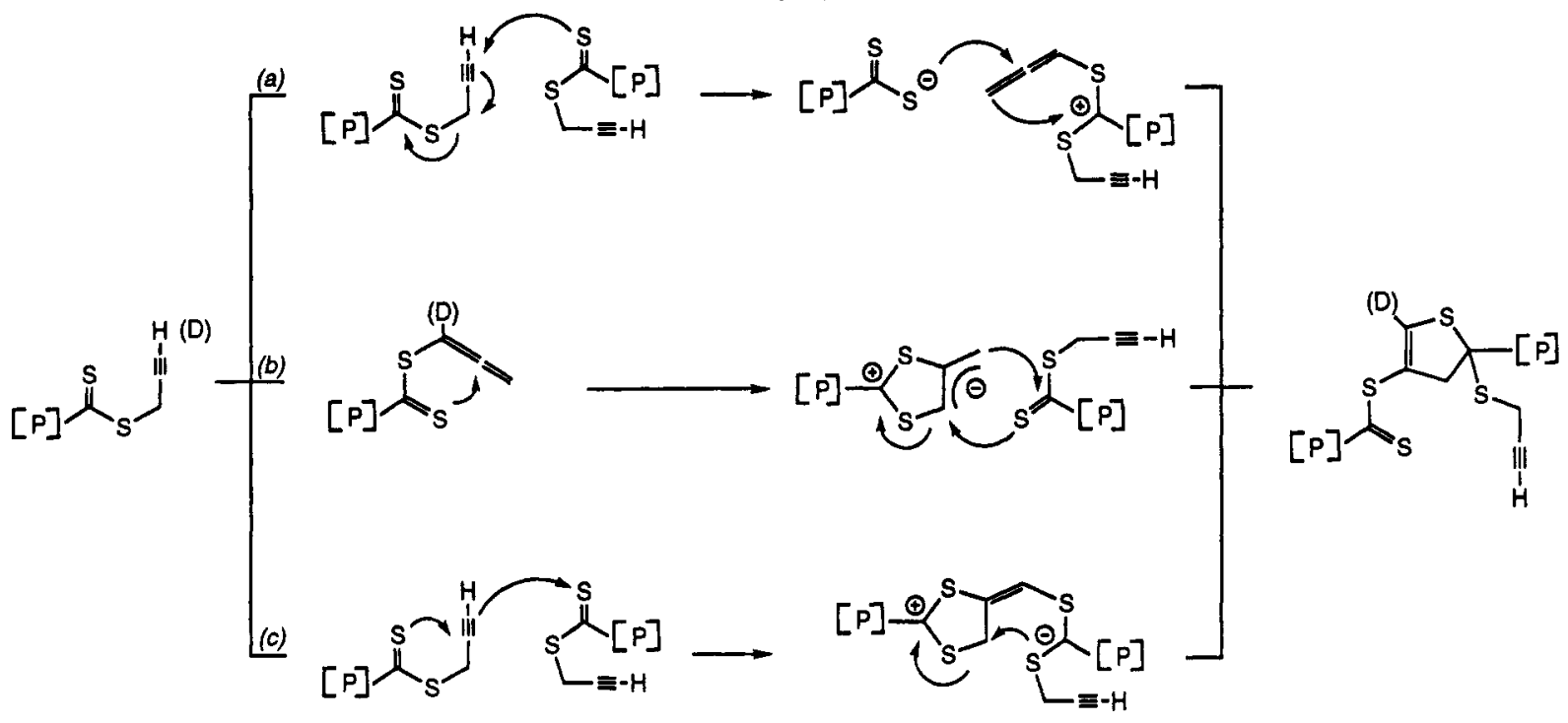<smiles>C#C[Te]P(=O)([O-])[P+]([O-])([O-])[O-]</smiles>

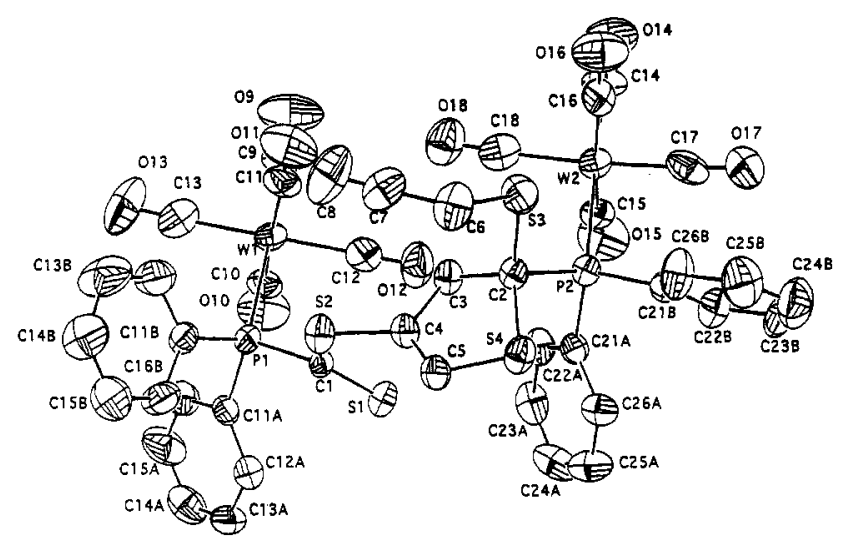

Figure 1. X-ray crystal structure with atom-numbering scheme for the complex $\mathrm{W}_{2}(\mathrm{CO})_{10}\left[\mathrm{P}_{2} \mathrm{Ph}_{4}\left(\mathrm{C}_{8} \mathrm{H}_{6} \mathrm{~S}_{4}\right)\right](3)$. Selected bond distances $(\AA)$ and angles (deg) are as follows: $\mathrm{W}_{1}-\mathrm{P}_{1}, 2.526(3) ; \mathrm{W}_{2}-\mathrm{P}_{2}, 2.560(3) ; \mathrm{C}_{1}-\mathrm{S}_{1}, 1.611(1) ; \mathrm{C}_{1}-\mathrm{S}_{2}, 1.753-$ (10); $\mathrm{S}_{2}-\mathrm{C}_{4}, 1.743(11) ; \mathrm{C}_{3}-\mathrm{C}_{4}, 1.487(15) ; \mathrm{C}_{4}-\mathrm{C}_{5}, 1.323(16) ; \mathrm{P}_{1-}$ $\mathrm{C}_{1}, 1.843(10) ; \mathrm{P}_{2}-\mathrm{C}_{2}, 1.916(10) ; \mathrm{C}_{2}-\mathrm{C}_{3}, 1.538(15) ; \mathrm{C}_{2}-\mathrm{S}_{4}$, $1.853(11) ; \mathrm{C}_{2}-\mathrm{S}_{3}, 1.817(10) ; \mathrm{S}_{3}-\mathrm{C}_{6}, 1.815(12) ; \mathrm{C}_{6}-\mathrm{C}_{7}, 1.453-$ (21); $\mathrm{C}_{7}-\mathrm{C}_{8}, 1.155(22) ; \mathrm{S}_{2}-\mathrm{C}_{1}-\mathrm{S}_{1}, 124.6(6) ; \mathrm{C}_{2}-\mathrm{C}_{3}-\mathrm{C}_{4}, 108.0$ (8); $\mathrm{C}_{3}-\mathrm{C}_{4}-\mathrm{C}_{5}, 115.4(10) ; \mathrm{C}_{4}-\mathrm{C}_{5}-\mathrm{S}_{4}, 116.1(8) ; \mathrm{C}_{5}-\mathrm{S}_{4}-\mathrm{C}_{2}, 90.9(5)$; $\mathrm{C}_{3}-\mathrm{C}_{2}-\mathrm{S}_{4}, 107.1(7) ; \mathrm{C}_{2}-\mathrm{S}_{3}-\mathrm{C}_{6}, 102.5(5) ; \mathrm{C}_{6}-\mathrm{C}_{7}-\mathrm{C}_{8}, 179.7(17)$.

Interestingly, the free phosphines $\mathrm{PPh}_{2}\left(\mathrm{CS}_{2} \mathrm{CH}_{3}\right)$ and $\mathrm{PPh}_{2}\left(\mathrm{CS}_{2} \mathrm{C}_{3} \mathrm{H}_{5}\right)$ are readily prepared by the alkylation of $\mathrm{PPh}_{2} \mathrm{CS}_{2}$ and are less stable than the corresponding coordinated phosphines. However, our attempts to prepare $\mathrm{PPh}_{2}\left(\mathrm{CS}_{2} \mathrm{C}_{3} \mathrm{H}_{3}\right)$ were unsuccessful.

Three possible pathways for the transformation of 2 to 3 are depicted in Scheme 1. The cyclization may proceed via an intermolecular anionotropic rearrangement (path-

(9) Crystal data for 3: $\mathrm{C}_{42} \mathrm{H}_{28} \mathrm{O}_{10} \mathrm{P}_{2} \mathrm{~S}_{4} \mathrm{~W}_{2}$, space group $P \overline{1}, a=10.054$ (9) $\AA, b=14.960(6) \AA, c=16.444(7) \AA, \alpha=112.45(3)^{\circ}, \beta=101.40(5)^{\circ}$, $\gamma=91.41(5)^{\circ}, V=2227(2) \AA^{3}, Z=2, D_{\mathrm{c}}=1.862 \mathrm{~g} \mathrm{~cm}^{-3}, \mu=55.767 \mathrm{~cm}^{-1}$, 4199 observed reflections, $2 \theta_{\max }=45^{\circ}, R=0.035, R_{\mathrm{w}}=0.028 ; T=298$ K. Crystal data for 8: $\mathrm{C}_{20} \mathrm{H}_{13} \mathrm{BF}_{4} \mathrm{NO}_{6} \mathrm{PS} \mathrm{S}_{2} \mathrm{~W}$, space group $P 2_{1} / c, a=$ $16.1947(20) \AA, b=8.0236(20) \AA, c=19.580(4) \AA, \beta=90.550(12)^{\circ}, V=$ 2544.1(9) $\AA^{3}, Z=4, D_{\mathrm{c}}=1.862 \mathrm{~g} \mathrm{~cm}^{-3}, \mu=49.153 \mathrm{~cm}^{-1}, 3331$ observed reflections, $2 \theta_{\max }=45^{\circ}, R=0.037, R_{\mathrm{y}}=0.030$.

(10) Cotton, F. A.; Wilkinson, G. Aduanced Inorganic Chemistry, 4th ed.; Wiley: New York, 1980; p 209. way a) of the $S$-propargyl group to the allenic isomer, followed by electrophile-initiated addition to allene. The alternative pathway $b$ involves an intramolecular ${ }^{11}$ rearrangement of the $S$-propargyl group to the allenic isomer followed by a formal $3+2$ cycloaddition, ${ }^{12}$ i.e. addition of the allylic type anion to the $\mathrm{C}=\mathrm{S}$ bond followed by cyclization. It seems likely that, in both cases, the (diphenylphosphine)tungsten group plays a key role in stabilizing the cationic center generated in the first step. The new stepwise process depicted in pathway $c$ is yet another possible alternative. To distinguish between these mechanisms, the following reactions have been carried out. Pathway $a$ produces 1 , which is known to react rapidly with $\mathrm{MeI}$ to form $\mathrm{W}(\mathrm{CO})_{5}\left[\mathrm{PPh}_{2}\left(\mathrm{CS}_{2} \mathrm{CH}_{3}\right)\right](6)$, and the dimerization of 2 is a relatively slower process than the alkylation reaction of 1 . We thus carried out the dimerization in the presence of a 100 -fold excess of MeI. The expected product 6 is not observed. Consistent with this observation, the presence of 1 in excess did not retard the dimerization reaction. These results eliminate the existence of 1 during the reaction. Furthermore, at room temperature, the reaction occurs only in hexane or ether; in a polar solvent such as $\mathrm{CH}_{3} \mathrm{CN}$ or THF, no reaction is observed. It is therefore less likely that the dimerization proceeds via pathway $a$. Deuterium labeling at the terminal alkyne of 2 gives the dimerization product with deuterium being found at the olefinic site of the fivemembered ring and at the terminus of the unchanged propargyl group. The protonation reactions described below provide evidence against pathway $b$.

The protonation of 2 affords the red crystalline complex $\mathrm{W}(\mathrm{CO})_{5}\left[\mathrm{PPh}_{2}\left(\mathrm{CS}_{2} \mathrm{C}_{3} \mathrm{H}_{4}\right)\right] \mathrm{BF}_{4}(4)$ in $87 \%$ isolated yield. The mass spectrum of 4 suggests that this product is a monomer. In the ${ }^{1} \mathrm{H}$ NMR spectrum, ${ }^{8}$ the vinylic proton and methyl protons are observed at $\delta 8.98$ and 2.85, 5874.

(11) Boivin, J.; Tailhan, C.; Zard, S. Z. J. Am. Chem. Soc. 1991, 113,

(12) (a) Yamago, S.; Nakamura, E. J. Am. Chem. Soc. 1989, 111, 7285. (b) Boger, D. L.; Brotherton, C. E. J. Am. Chem. Soc. 1984, 106, 805; 1986 , 108, 6695. (c) Danheiser, R. L.; Carini, D. J.; Basak, A. J. Am. Chem. Soc. $1981,113,1604$. 
Scheme 2<smiles></smiles>

4

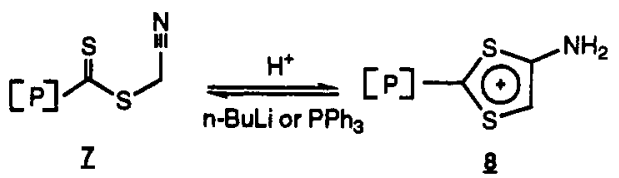

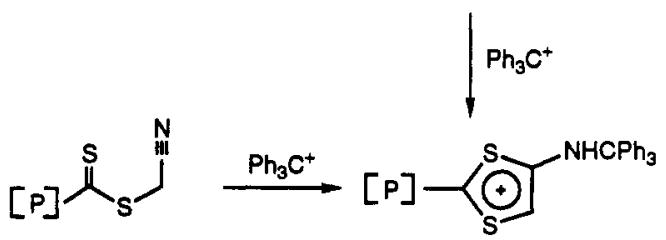

9

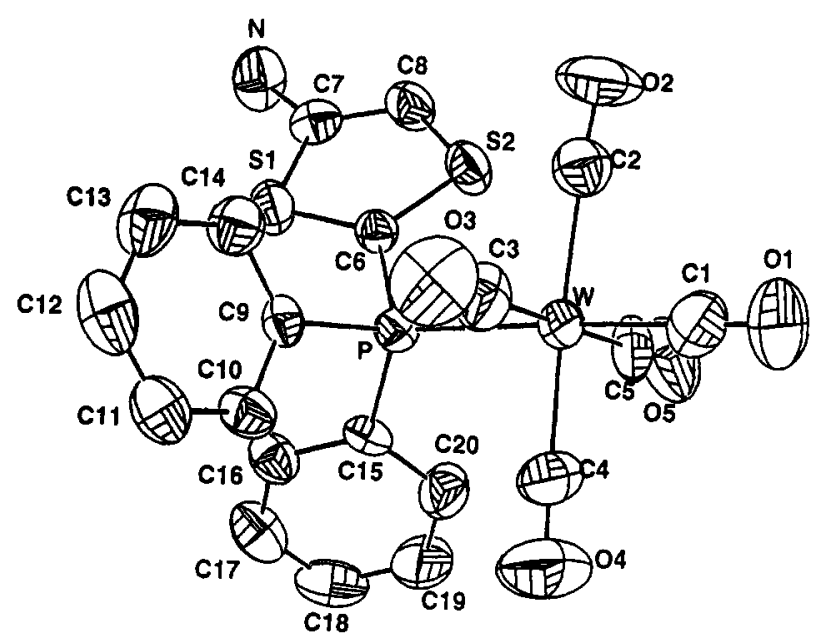

Figure 2. X-ray crystal structure with atom-numbering scheme for the complex W(CO) $)_{5}\left[\mathrm{PPh}_{2}\left(\mathrm{CS}_{2} \mathrm{C}_{2} \mathrm{NH}_{3}\right)\right] B \mathrm{BF}_{4}(8)$. Selected bond distances $(\AA)$ and angles (deg) are as follows: $\mathrm{W}-\mathrm{P}, 2.498(2) ; \mathrm{P}-\mathrm{C}_{6}, 1.820(9) ; \mathrm{C}_{6}-\mathrm{S}_{1}, 1.685(8) ; \mathrm{C}_{7}-\mathrm{S}_{1}, 1.713-$ (10); $\mathrm{C}_{6}-\mathrm{S}_{2}, 1.648(9) ; \mathrm{S}_{2}-\mathrm{C}_{8}, 1.670(10) ; \mathrm{C}_{7}-\mathrm{C}_{8}, 1.371(13) ; \mathrm{C}_{7}$ $\mathrm{N}, 1.351(12) ; \mathrm{S}_{2}-\mathrm{C}_{6}-\mathrm{S}_{1}, 114.2(5) ; \mathrm{C}_{2}-\mathrm{C}_{3}-\mathrm{C}_{4}, 108.0(8) ; \mathrm{C}_{3}-\mathrm{C}_{4}-$ $\mathrm{C}_{5}, 115.4(10) ; \mathrm{C}_{4}-\mathrm{C}_{5}-\mathrm{S}_{4}, 116.1(8) ; \mathrm{C}_{5}-\mathrm{S}_{4}-\mathrm{C}_{2}, 90.9(5) ; \mathrm{C}_{3}-\mathrm{C}_{2}-$ $\mathrm{S}_{4}, 107.1(7) ; \mathrm{C}_{2}-\mathrm{S}_{3}-\mathrm{C}_{6}, 102.5(5) ; \mathrm{C}_{6}-\mathrm{C}_{7}-\mathrm{C}_{8}, 179.7(17)$.

respectively, with coupling constants ${ }^{4} J_{\mathrm{H}-\mathrm{H}}$ of $1.0 \mathrm{~Hz}$. The downfield shift of the vinylic proton indicates the presence of a cationic five-membered ring. Protonation of 7 also gives the cyclization product $\mathrm{W}(\mathrm{CO})_{5}\left[\mathrm{PPh}_{2}\left(\mathrm{CS}_{2} \mathrm{C}_{2} \mathrm{HNH}_{2}\right)\right]$ $\mathrm{BF}_{4}(8){ }^{8}$ The vinylic and amine protons in the ${ }^{1} \mathrm{H}$ NMR spectrum of 8 are observed at $\delta 8.20$ and 8.12 , respectively. As shown in Scheme 2, the reaction of 7 with $\mathrm{Ph}_{3} \mathrm{CBF}_{4}$ gives the similar cyclization product $\mathrm{W}(\mathrm{CO})_{5}\left[\mathrm{PPh}_{2}\left(\mathrm{CS}_{2} \mathrm{C}_{2}\right.\right.$ $\left.\mathrm{HNHCPh}_{3}\right) \mathrm{JBF}_{4}(9){ }^{8}$ Protonation of 2 to 4 is not reversible, but deprotonation of 8 by $n$-BuLi produces 7 quantitatively. The ORTEP drawing of 8 is shown in Figure 2. Localization of the cationic charge at the fivemembered ring is indicated by the ring bond lengths. All four C-S bonds are about equal length (1.65(1)-1.71(1) $\AA$ ) with the $\mathrm{C}(7)-\mathrm{C}(8)$ distance of $1.37(1) \AA$ lying in the range of a typical aromatic $\mathrm{C}-\mathrm{C}$ separation. Protonation of $\mathbf{2}-d_{1}$, i.e. $98 \%$ deuterium labeling at the terminal alkyne, resulted in product with $87 \% \mathrm{D}$ labeling at the methyl group. Protonation using $\mathrm{CF}_{3} \mathrm{COOD}$ results in the formation of
Scheme 3
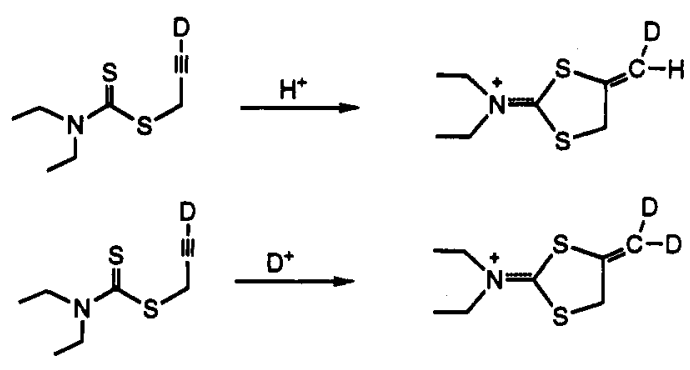

a $\mathrm{CHD}_{2}$ unit in 4. Protonation of $\mathrm{Et}_{2} \mathrm{NCS}_{2} \mathrm{CH}_{2} \mathrm{C} \equiv \mathrm{CD}$ gives the cyclization product $\mathrm{Et}_{2} \mathrm{NCS}_{2} \mathrm{CH}_{2} \mathrm{C}=\mathrm{CHD}^{+}$, in which $\mathrm{D}$ is also incorporated at the olefinic side chain (see Scheme 3). If the product formed via pathway $b$, D labeling would appear at the allylic methylene. Thus, these deuterium labeling studies exclude $b$ as the viable pathway. To probe whether the reaction proceeds via a radical mechanism, ${ }^{13}$ it was conducted in the presence of AIBN under photolytic conditions. The rate of the reaction and the yield of the product did not change. The observed solvent effect along with the results described above indicate that $c$ in Scheme 1 is most likely the pathway for the dimerization of 2 . The $\mathrm{C}=\mathrm{S}$ group assists in the formation of the intermolecular $\mathrm{C}-\mathrm{S}$ bond, producing the dimeric zwitterionic intermediate. This is followed by ring closure to give the product.

Alkynes with electron-withdrawing substituents are known to react with $\eta^{2}$-CS 2 or $\eta^{2}$-SCNR metal complexes to give 1,3-dithiol-2-ylidene ${ }^{14}$ or 1,3-thiazol-2-ylidene ${ }^{15}$ derivatives. Syntheses of five-membered-ring thiosulfinate esters from metal 2-alkynyl complexes have been reported by Welker and co-workers. ${ }^{16}$ The $[2+2]$ condensation of an alkyne with $\eta^{2}-\mathrm{CS}_{2}$ has also been reported. ${ }^{17}$ The cyclization of the propargyl and thiocarbonyl groups promoted by the $S$ atom discussed above is, to our knowledge, the first example of a sulfur-assisted cyclization reaction. Reactivities of the metal ((propargylthio)thiocarbonyl)phosphine complex and its utility in synthetic chemistry are currently under investigation.

Acknowledgment. We thank the National Science Council of the Republic of China for financial support. We thank Professor T. Y. Luh for useful suggestions. A reviewer is also gratefully acknowledged for providing useful references.

Supplementary Material Available: Text giving details of the spectroscopic data of complexes 3, 4, and 7-9 and data for the X-ray structural determination of complexes 3 and 8 , including tables of crystal data and refinement details, atomic coordinates, anisotropic thermal parameters, and bond distances and bond angles (14 pages). Ordering information is given on any current masthead page.

\section{OM940067T}

(13) (a) Barton, D. H. B. Tetrahedron 1992, 48, 2529. (b) Forrest, D.; Ingold, K. U.; Barton, D. H. B. J. Phys. Chem. 1977, 81, 915.

(14) (a) Le Bozec, H.; Gorgues, A.; Dixneuf, P. H. Inorg. Chem. 1981, 20, 2486. (b) Bianchini, C.; Meli, A.; Scapacci, G. Organometallics 1984, 4, 264. (c) Frazier, C. C.; Magnussen, N. D.; Osuji, L. N.; Parker, K. O. Organometallics 1982, 1, 903. (d) Schenk, W. A.; Scwietze, T.; Muller, H. J. Organomet. Chem. 1982, 232, C41.

(15) Ngounda, M.; Le Bozec, H.; Dixneuf, P. H. J. Org. Chem. 1982, 42,4000 .

(16) Raseta, M. E.; Mishra, R. K.; Cawood, S. A.; Welker, M. E.; Rheingold, A. L. Organometallics 1991, 10, 2936.

(17) Bianchini, C.; Mealli, C.; Meli, A.; Sabat, M.; Silvestrè, J.; Hoffmann, R. Organometallics $1986,5,1733$. 